\title{
Plausible ergogenic effects of vitamin D on athletic performance and recovery
}

\author{
Dylan T. Dahlquist ${ }^{2}$, Brad P. Dieter ${ }^{3}$ and Michael S. Koehle ${ }^{1^{*}}$
}

\begin{abstract}
The purpose of this review is to examine vitamin $D$ in the context of sport nutrition and its potential role in optimizing athletic performance. Vitamin D receptors (VDR) and vitamin D response elements (VDREs) are located in almost every tissue within the human body including skeletal muscle. The hormonally-active form of vitamin $D$, 1,25-dihydroxyvitamin $D$, has been shown to play critical roles in the human body and regulates over 900 gene variants. Based on the literature presented, it is plausible that vitamin $D$ levels above the normal reference range (up to $100 \mathrm{nmol} / \mathrm{L}$ ) might increase skeletal muscle function, decrease recovery time from training, increase both force and power production, and increase testosterone production, each of which could potentiate athletic performance. Therefore, maintaining higher levels of vitamin D could prove beneficial for athletic performance. Despite this situation, large portions of athletic populations are vitamin D deficient. Currently, the research is inconclusive with regards to the optimal intake of vitamin D, the specific forms of vitamin D one should ingest, and the distinct nutrient-nutrient interactions of vitamin $\mathrm{D}$ with vitamin $\mathrm{K}$ that affect arterial calcification and hypervitaminosis. Furthermore, it is possible that dosages exceeding the recommendations for vitamin $D$ (i.e. dosages up to 4000-5000 IU/day), in combination with 50 to $1000 \mathrm{mcg} /$ day of vitamin $\mathrm{K}_{1}$ and $\mathrm{K}_{2}$ could aid athletic performance. This review will investigate these topics, and specifically their relevance to athletic performance.
\end{abstract}

Keywords: Vitamin D, Performance, Skeletal muscle, Vitamin K, Dosage, Athlete, Testosterone, Hormones, Recovery

\section{Introduction}

Vitamin D, a fat-soluble vitamin, was first discovered in cod liver oil [1] and has since been identified as an essential vitamin, acting as a precursor steroid to a host of metabolic and biological processes. Once converted into its biologically-active form, 1,25-dihydroxyvitamin D [2], it regulates the expression of over 900 gene variants [3]. These gene expressions have been shown to have significant impact on a wide variety of health and performance-related variables, such as exercise-induced inflammation, tumour suppressor genes, neurological function, cardiovascular health, glucose metabolism, bone health and skeletal muscle performance [4-10]. Surprisingly enough, $88.1 \%$ of the world's population has inadequate vitamin D levels [11]. Deficiency has been shown to be linked to a variety of adverse psychological and health outcomes, such as suicidal thoughts

\footnotetext{
* Correspondence: michael.koehle@ubc.ca

${ }^{1}$ Simon Fraser University, Biomedical Physiology and Kinesiology (BPK), 8888 University Drive - Burnaby, Vancouver, BC V5A 1S6, Canada

Full list of author information is available at the end of the article
}

[12], depression [13], cognitive decline and neurological impairment [14], and an increased risk of cancer [15]. Furthermore, individuals with inefficient vitamin D stores have an increased risk of bone disorders like spondyloarthritis [16], rickets [1, 17], and fractures due to higher bone resorption from an overproduction of parathyroid hormone (PTH) $[18,19]$. Lastly, deficiency has catabolic effects on muscle tissue [20], causes muscle weakness [21], and impairs cross-bridge formation [22], all of which could impair athletic performance. Due to the increase in enzymatic activity of exercise [23], athletes may be as susceptible, if not more susceptible to becoming vitamin $\mathrm{D}$ deficient when compared to the general population. A recent meta-analysis pooling 23 studies with 2313 athletes found that $56 \%$ of athletes had inadequate vitamin D levels [24]. Because of the high prevalence of vitamin D deficiency [25] and its effects on human physiology, this review is aimed to identify the role of vitamin D in athletic performance (for health related aspects of vitamin $\mathrm{D}$, see $[11,18,26,27])$. This review will cover how vitamin D is metabolized in the body, its 
potential roles in athletic performance, sources of vitamin $\mathrm{D}$, differences between vitamin $\mathrm{D}_{2}$ and vitamin $\mathrm{D}_{3}$, optimal levels of vitamin $\mathrm{D}$ for athletes, and strategies to achieve these levels and prevent toxicity by nutrientnutrient interactions.

\section{Metabolism of vitamin D}

Vitamin D travels in the bloodstream bound to vitamin Dbinding proteins [28] and undergoes a three-stage process of key enzymatic reactions [Fig. 1]: 25-hydroxylation, $1 \alpha-$ hydroxylation and 24-hydroxylation [18, 29]. The steroid precursor vitamin $\mathrm{D}_{3}$ first travels to the liver where it is hydroxylated to 25 -hydroxyvitamin $\mathrm{D}[25(\mathrm{OH}) \mathrm{D}]$ by 25 hydroxlayse, which is mediated by the cytochrome P450 enzymes, CYP27A1 (in the mitochondria) and CYP2R1 [29]. This $25(\mathrm{OH}) \mathrm{D}$ is then hydroxylated by CYP27B1 (1 $\alpha$-hydroxylation) [29]. This final step occurs primarily in the kidney [18], but various other tissues, namely skeletal muscle, have also been shown to express CYP24A1 enzymes, where $25(\mathrm{OH}) \mathrm{D}$ becomes the active hormonal form, 1,25-dihydroxyvitamin D [29]. 1,25-dihydroxyvitamin D then interacts with vitamin D receptors (VDR), which are located in almost every tissue in the body $[30,31]$, and is then transcribed into the cell and binds to vitamin $\mathrm{D}$ response elements (VDREs) located in DNA [18]. If 1,25-dihydroxyvitmain D does not interact with VDREs, it is further degraded by CYP24A1 (24-hydroxylase) to the inactive form, calcitroic acid [29].

\section{Vitamin $D$ and performance}

Vitamin $D_{3}$ receptors exist in human skeletal muscle tissue $[30,31]$, indicating that 1,25-dihydroxyvitamin $\mathrm{D}$ has a direct effect on skeletal muscle activity. Research on the muscle effects of vitamin $\mathrm{D}_{3}$ [32] is limited to diseased populations [20,33], or healthy untrained adults [34]. Until recently, a few reviews and meta-analyses have shown that increasing serum 25(OH)D levels in a given population have a positive effect on muscle strength, power and mass [33-35] but the only study that examined the effects in athletes [36], had mixed results. In addition, von Hurst and Beck [36] concluded that the optimal intake and serum concentration of $25(\mathrm{OH}) \mathrm{D}$ have yet to be identified in the athletic population.

\section{Maximal oxygen uptake}

Vitamin D receptors (VDR) are present in cardiac muscle and vascular tissue [7], indicating that 1,25-dihydroxyvitamin D might influence maximal oxygen uptake $\left(\mathrm{VO}_{2} \mathrm{max}\right)$ via the ability to transport and utilize oxygen within the blood to various tissues. Multiple correlative studies showed a positive correlation between $\mathrm{VO}_{2}$ max and serum 25(OH)D concentration in non-athletes [Table 1] [37-39]. However many confounding variables were not addressed, such as concomitant multivitamin [38] and supplement intake [37, 39]. Studies performed in athletes are conflicting. Koundourakis and his colleagues [40] found that there was a significant correlation between $25(\mathrm{OH}) \mathrm{D}$ levels and performance parameters in 67 Caucasian male professional soccer players (age $25.6 \pm 6.2$ ). A linear relationship was seen between pre- and post- offseason measurements of $25(\mathrm{OH}) \mathrm{D}$ and muscle strength indicated by squat jump (SJ), countermovement jump (CMJ), sprinting ability (10and 20 - $\mathrm{m}$ sprint) and $\mathrm{VO}_{2} \max$ [40]. A more recent publication by Fitzgerald et al. [41], concluded that there was no association between $25(\mathrm{OH}) \mathrm{D}$ levels and an individual's

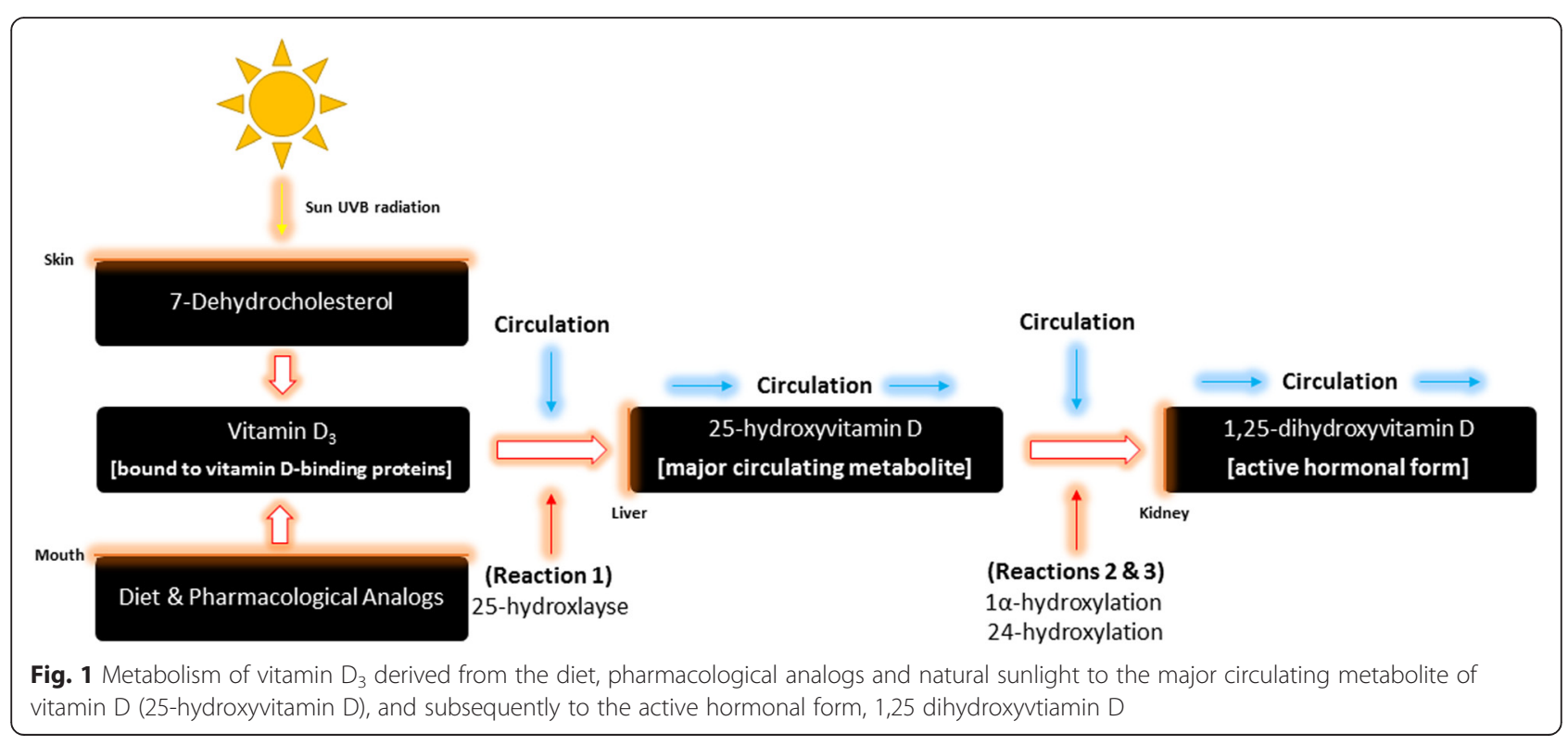


Table 1 Vitamin D correlation and intervention studies on Maximal Oxygen Uptake (VO2max)

\begin{tabular}{|c|c|c|c|c|c|c|c|}
\hline Author & $\begin{array}{l}\text { Reference } \\
\#\end{array}$ & Population & Subjects/Specimens & $\begin{array}{l}\text { Type of } \\
\text { study }\end{array}$ & Intervention & Duration & Results \\
\hline $\begin{array}{l}\text { Gregory et al. } \\
2013\end{array}$ & {$[37]$} & $\begin{array}{l}\text { Healthy } \\
\text { adults }\end{array}$ & $\begin{array}{l}213 \text { Healthy Male } \\
(N=104) \text { and Female } \\
(N=109) \text { Adults } \\
(44.8 \pm 16.4)\end{array}$ & Correlation & $\begin{array}{l}3 \text { Groups: Deficient } \\
(<50 \mathrm{nmol} / \mathrm{L}, N=16), \\
\text { Insufficient }(>50 \mathrm{nmol} / \mathrm{L}, \\
\text { but }<75 \mathrm{nmol} / \mathrm{L}, N=57) \\
\text { Sufficient }(>75 \mathrm{nmol} / \mathrm{L} \text {, } \\
N=140)\end{array}$ & 6 Months & $\begin{array}{l}\text { Aerobic Fitness } \\
\text { Not Affected by } \\
25(\mathrm{OH}) \text { D Levels }\end{array}$ \\
\hline $\begin{array}{l}\text { Mowry, } \\
\text { Costello \& } \\
\text { Heelan } 2007\end{array}$ & {$[38]$} & $\begin{array}{l}\text { Mixed } \\
\text { females }\end{array}$ & $\begin{array}{l}59 \text { Non-Trained } \\
\text { Females (age 16to 24; } \\
19.86 \pm 2.13), 55 \\
\text { Caucasian and } 4 \\
\text { Asian (VO2 } \mathrm{max} \text { of } \\
39.10 \pm 7.18 \mathrm{~mL} / \mathrm{kg} / \mathrm{min} \text { ) }\end{array}$ & Correlation & $\begin{array}{l}\text { Serum } 25(\mathrm{OH}) \mathrm{D} \text { Levels } \\
\text { of } 46.19 \pm 20.14 \mathrm{ng} / \mathrm{mL}\end{array}$ & - & $\begin{array}{l}\text { Significant positive } \\
\text { association with } \\
\text { V02max and } \\
\text { 25(OH)D Levels \& } \\
\text { Significant inverse } \\
\text { assocation with } \\
\text { body fat and both V02 } \\
\text { max and 25(OH)D }\end{array}$ \\
\hline $\begin{array}{l}\text { Ardestani } \\
\text { et al. } 2011\end{array}$ & [39] & $\begin{array}{l}\text { Healthy } \\
\text { adults }\end{array}$ & $\begin{array}{l}200 \text { Healthy Adults } \\
\text { (age } 40 \pm 14.4), \\
\text { Male }(N=92) \text { and } \\
\text { Female }(N=108) \\
\text { (V02max of } 40 \pm 9.1 \\
\text { and } 30 \pm 8.5, \text { respectively) }\end{array}$ & Correlation & $\begin{array}{l}\text { Serum } 25(\mathrm{OH}) \mathrm{D} \text { levels } \\
\text { of } 34 \pm 13.3 \mathrm{ng} / \mathrm{mL}\end{array}$ & - & $\begin{array}{l}25(\mathrm{OH}) \mathrm{D} \\
\text { concentrations are } \\
\text { positively }(p=0.05) \\
\text { related to V02max \& } \\
\text { Significant Interaction } \\
\text { between } 25(\mathrm{OH}) \mathrm{D} \text { and } \\
\text { Self- Reported Hours } \\
\text { of Moderate to } \\
\text { Vigorous Physical } \\
\text { Activity (Higher } \\
25(\mathrm{OH}) \mathrm{D}=\text { Higher } \\
\text { Activity) }\end{array}$ \\
\hline $\begin{array}{l}\text { Koundourakis } \\
\text { et al. } 2014\end{array}$ & {$[40]$} & Athletes & $\begin{array}{l}67 \text { Caucasian Male } \\
\text { Professional Soccer } \\
\text { Players (age } 25.6 \pm 6.2 \text { ) }\end{array}$ & Correlation & $\begin{array}{l}\text { Performance Testing: } \\
\text { Squat Jump (SJ), } \\
\text { Countermovement Jump } \\
\text { (CMJ), } 10(10 \mathrm{~m}) \text { and } \\
20 \mathrm{~m}(20 \mathrm{~m}) \text { sprint, } \\
\text { Maximal Oxygen Uptake } \\
\text { (V02max), and anthropometry }\end{array}$ & $\begin{array}{l}6 \text { Weeks } \\
\text { (Pre Off- } \\
\text { Sea onto } \\
\text { Post Off- } \\
\text { Season) }\end{array}$ & $\begin{array}{l}\text { Significant correlations } \\
\text { between } 25(\mathrm{OH}) \mathrm{D} \text { and } \\
\text { ALL performance } \\
\text { parameters for both } \\
\text { PRE and POST } \\
\text { experimental sessions }\end{array}$ \\
\hline $\begin{array}{l}\text { Fitzgeral } \\
\text { et al. } 2014\end{array}$ & [41] & Athletes & $\begin{array}{l}52 \text { Caucasian } \\
\text { Competitive Ice } \\
\text { Hockey Players } \\
\text { (age } 20.1 \pm 1.5 \text { ) } \\
\text { (V02max } 54.6 \pm 4.3 \text { ) }\end{array}$ & $\begin{array}{l}\text { Cross- } \\
\text { sectional }\end{array}$ & $\begin{array}{l}\text { Performance Testing: } \\
\text { Maximal Oxygen Uptake } \\
\text { (V02peak), Max Heart } \\
\text { Rate (HR), Peak RER, } \\
\text { Total Exercise Time }\end{array}$ & $\begin{array}{l}1 \text { Month } \\
\text { Recruiting } \\
\text { Phase } \\
\text { During } \\
\text { Off-Season } \\
\text { (May to } \\
\text { June) }\end{array}$ & $\begin{array}{l}\text { All Athletes had } \\
25(\mathrm{OH}) \mathrm{D} \mathrm{Levels} \\
<.65 .0 \mathrm{ng} / \mathrm{mL}, 37.7 \% \\
\text { of the Athletes had } \\
25(\mathrm{OH}) \mathrm{D} \text { levels of } \\
<32 \mathrm{ng} / \mathrm{mL} \& \\
25(\mathrm{OH}) \mathrm{D} \text { status was } \\
\text { not significantly } \\
\text { associated with any } \\
\text { parameter measured }\end{array}$ \\
\hline $\begin{array}{l}\text { Forney et al. } \\
2014\end{array}$ & [42] & $\begin{array}{l}\text { Active } \\
\text { College } \\
\text { Students }\end{array}$ & $\begin{array}{l}39 \text { Physically Active } \\
\text { College Students } \\
\text { (20 Males, } 19 \text { Females) }\end{array}$ & Correlation & $\begin{array}{l}25(\mathrm{OH}) \mathrm{D} \text { Levels of } \\
20.97 \pm 1.97 \mathrm{ng} / \mathrm{mL} \\
(\mathrm{N}=20) \text { or } 44.15 \pm 2.17 \mathrm{ng} / \mathrm{mL} \\
(\mathrm{N}=19) \text { - Primary Outcomes: } \\
\text { BMl, \% Body Fat, Resting } \\
\text { Metabolic Rate, } \\
\text { Maximal Oxygen } \\
\text { Uptake (VO2max), } \\
\text { Power Output (Watts), } \\
\text { and Muscle Strength }\end{array}$ & - & $\begin{array}{l}\text { Significant positive } \\
\text { relationship seen } \\
\text { between V02max and } \\
25(\mathrm{OH}) \mathrm{D} \& \text { Significant } \\
\text { negative relationship } \\
\text { seen between BMl } \\
\text { and } 25(\mathrm{OH}) \mathrm{D}\end{array}$ \\
\hline $\begin{array}{l}\text { Jastrzebski } \\
2014\end{array}$ & [43] & Athletes & $\begin{array}{l}14 \text { Elite Lightweight } \\
\text { Rowers }\end{array}$ & $\begin{array}{l}\text { Intervention } \\
\text { - RCT }\end{array}$ & $\begin{array}{l}6000 \text { IU/day of Vita } \\
\text { min D3 vs Placebo in } \\
25(0 H) D \text { sufficient } \\
\text { athletes }(>30 \mathrm{ng} / \mathrm{mL})\end{array}$ & 8 Weeks & $\begin{array}{l}\text { Vitamin D vs Placebo: } \\
\text { Significant } \uparrow \text { in V02max } \\
(12.1 \% \text { and } 10.3 \%, \\
\text { respectively) and } \\
25(\mathrm{OH}) \mathrm{D} \text { concentrations } \\
\text { by } 400 \%(\sim 120 \mathrm{ng} / \mathrm{mL})\end{array}$ \\
\hline
\end{tabular}

$\mathrm{VO}_{2}$ max in 52 Caucasian competitive ice hockey players [41]. Additionally, the correlation commonly seen between the serum $25(\mathrm{OH}) \mathrm{D}$ concentrations and $\mathrm{VO}_{2} \max$ is inversely related to increases in physical activity and training status [39]. Forney and her colleagues [42] recently investigated the association between serum 
$25(\mathrm{OH}) \mathrm{D}, \mathrm{VO}_{2}$ max and training status in 39 physicallyactive college students (20 men, 19 women). They showed that the participants with higher ( $>35 \mathrm{ng}-\mathrm{mL}-1)$ serum 25(OH)D levels had a significantly higher $\mathrm{VO}_{2} \max (+20 \%)$ than the low $(<35 \mathrm{ng}-\mathrm{mL}-1)$ serum $25(\mathrm{OH}) \mathrm{D}$ group [42]. However, this correlation was limited to males only.

Intervention trials in the athletic population are scarce. To our knowledge, only one exists looking at the effects of vitamin D supplementation on $\mathrm{VO}_{2}$ max. Jastrzebski [43] performed a single-blinded trial of supplementation with $6000 \mathrm{IU} /$ day of vitamin $\mathrm{D}_{3}$ versus a placebo during an 8week training cycle in 14 elite lightweight rowers with sufficient $25(\mathrm{OH}) \mathrm{D}$ concentrations $(>30 \mathrm{ng} / \mathrm{mL})$. They demonstrated a significantly increase in $\mathrm{VO}_{2} \max (12.1 \%$ and $10.3 \%$, respectively) and $25(\mathrm{OH}) \mathrm{D}$ concentrations by $400 \%(\sim 120 \mathrm{ng} / \mathrm{mL})$. The authors concluded that supplementation of vitamin $\mathrm{D}_{3}$ during the 8-week training period significantly improved aerobic metabolism in the elite rowers [43]. Further research is needed to test whether an ergogenic effect exists in athletes who are severely deficient in serum $25(\mathrm{OH}) \mathrm{D}$, and if supraphysiological dosages of vitamin $\mathrm{D}_{3}$, such as that used by Jastrzebski, have an ergogenic effect in vitamin D replete athletes in other sport disciplines.

The specific mechanism by which increased levels of $25(\mathrm{OH}) \mathrm{D}$ affect $\mathrm{VO}_{2}$ max remains unclear [39], however this phenomenon could be due to the fact that the CYP enzymes that activate vitamin $D_{3}$ into 1,25 -dihydroxyvitamin $\mathrm{D}_{3}$ have heme-containing proteins [44] and could potentially affect the binding affinity of oxygen to hemoglobin.

\section{Recovery}

The ability to recover rapidly is important for athletes to train at high intensities more frequently. Human skeletal muscle tissue responds to training stimuli and/ or tissue damage through remodeling [45-47]. During recovery, 1,25-dihydroxyvitamin $\mathrm{D}$ increases the myogenic differentiation and proliferation [48] and downregulates myostatin, an inhibitory regulator of muscle synthesis of C2C12 myoblasts in culture [49]. Stratos and colleagues [50] showed this marked increase in skeletal muscle regeneration in a crushed soleus muscle (in vivo) of 56 male Wistar rats (300 to 325 g body weight), after a supraphysiological dose of $\sim 100,000$ IU of vitamin D. They [50] separated rats into a high $(332,000 \mathrm{IU} / \mathrm{kg})$ and low $(33,200 \mathrm{IU} / \mathrm{kg})$ dose groups and examined recovery response times to the crushed soleus muscle. When compared to the low dose group, the high dose group had a significant attenuation of apoptosis four days post-injury, indicative of an increase in cellular matrix proteins [50]; which is crucial for skeletal tissue repair [51]. This increase in cellular turnover rate led to the enhanced recovery time, an increase in tetanic force production (only $10 \%$ lower than the non-injured limb), and an increase in twitch force when compared to the control group [50]. As murine models display regenerative capacities that exceed those of humans, it is important to note the limitations of extending the aforementioned findings to humans; however, the finding that vitamin D supplementation enhances the recovery in peak isometric force shortly after intense exercise was recently supported in much lower doses in modestly-active humans [52].

In a randomized, double-blind, placebo-controlled study, Barker et al. [52] demonstrated that $4000 \mathrm{IU} /$ day for 35 days of vitamin D in healthy and moderately active adults attenuated the inflammatory biomarkers alanine (ALT) and aspartate (AST) immediately following 10 sets of 10 repetitions of peak isometric force eccentric-concentric jumps. Furthermore, although peak power output decreased in both the groups, the supplementation group only decreased by $6 \%$, while the placebo group's power decreased by $32 \%$ immediately post-exercise [52]. This discrepancy persisted at $48 \mathrm{~h}$ [52]. Further research examining higher dosages would be warranted to determine if recovery and power output are improved to a greater degree [Table 2].

\section{Force and power production}

Vitamin $D_{3}$ has also been shown to increase force and power output of skeletal muscle tissue [19], perhaps through the sensitization of calcium binding sites on the sarcoplasmic reticulum, leading to an enhanced crossbridge cycling and muscular contraction [53]. There is further evidence that vitamin $\mathrm{D}_{3}$ might also potentially increase both size and number of type II muscle fibers $[20,54,55]$. These findings have only been supported in mobility-limited elderly ( $\geq 65$ years old) women [55], and have yet to be tested in the athletic population. On the other hand, increases in force and power production have been studied in athletes with positive results during a randomized placebo-controlled study in 10 male professional soccer players [56]. After an 8-week long intervention of either receiving $5000 \mathrm{IU} /$ day of vitamin $\mathrm{D}_{3}$ or a placebo, the vitamin $D_{3}$ group had a significant increase in serum $25(\mathrm{OH}) \mathrm{D}$ levels and a significant improvement in both their 10-m sprint times and vertical jump when compared to the placebo group [56]. Confounding variables were well-controlled, in that the authors instructed the athletes to maintain current nutritional intake, and excluded any athlete who was taking a multivitamin, vitamin D, fish oil and/or were regular sunbed users or who just returned from a vacation in a sunlight enriched climate. However, other studies have shown no significant benefit of vitamin $\mathrm{D}$ supplementation in athletes with moderately deficient or adequate levels [10,41, 42], indicating that these 
Table 2 Vitamin D in vitro, in vivo and intervention studies on recovery

\begin{tabular}{|c|c|c|c|c|c|c|c|}
\hline Author & Reference\# & Population & Subjects/Specimens & $\begin{array}{l}\text { Type of } \\
\text { Study }\end{array}$ & Intervention & Duration & Results \\
\hline $\begin{array}{l}\text { Garcia } \\
\text { et al. } \\
2013\end{array}$ & {$[48]$} & $\begin{array}{l}\text { Human - } \\
\text { Ex Vivo }\end{array}$ & Human Myoblasts & In Vitro & $\begin{array}{l}\text { C2C12 Myoblasts treated } \\
\text { with } 100 \mathrm{nM} \text { of 1,25-D3 } \\
\text { or Placebo }\end{array}$ & $\begin{array}{l}1,4 \text {, and } \\
10 \text { Days }\end{array}$ & $\begin{array}{l}\uparrow \text { in Myogenic } \\
\text { Differentiation \& } \\
\text { Proliferation }\end{array}$ \\
\hline $\begin{array}{l}\text { Garcia } \\
\text { et al. } \\
2011\end{array}$ & [49] & $\begin{array}{l}\text { Human - } \\
\text { Ex Vivo }\end{array}$ & Human Myoblasts & In Vitro & $\begin{array}{l}\text { C2C12 Myoblasts treated } \\
\text { with } 100 \text { nM of 1,25- D3 } \\
\text { or Placebo }\end{array}$ & $\begin{array}{l}1,3,4 \\
7, \text { and } \\
10 \text { Days }\end{array}$ & $\begin{array}{l}\text { Down-regulation of } \\
\text { Myostatin }\end{array}$ \\
\hline $\begin{array}{l}\text { Stratos } \\
\text { et al. } \\
2013\end{array}$ & {$[50]$} & Rat Model & 56 Male Wistar Rats & $\begin{array}{l}\text { Intervention } \\
\text { - In Vivo }\end{array}$ & $\begin{array}{l}\text { High Dose Group: } \\
332,000 \text { III/kg Low Dose } \\
\text { Group: } 33,200 \text { IU/kg- } \\
\text { Regeneration of Crushed } \\
\text { Soleus Muscle }\end{array}$ & 42 Days & $\begin{array}{l}\text { High vs Low: (1) } \downarrow \text { in } \\
\text { Apoptosis (2) } \uparrow \text { in Cellular } \\
\text { Matrix Proteins (3) } \uparrow \\
\text { Tectonic Force Production } \\
\text { (4) Enhanced Recovery }\end{array}$ \\
\hline $\begin{array}{l}\text { Barker } \\
\text { et al. } \\
2013\end{array}$ & {$[52]$} & $\begin{array}{l}\text { Healthy \& } \\
\text { Active } \\
\text { Males }\end{array}$ & $\begin{array}{l}28 \text { Mode rat ly Active }(30-\text { min } \\
\text { of exercise } 3 x W e e k) \text { Males } \\
\text { (Vitamin D Group Age }=30 \pm 6 \text {, } \\
N=14) ;(\text { Placebo Group Age } \\
=31 \pm 5, N=14)\end{array}$ & $\begin{array}{l}\text { Intervention } \\
- \text { RCT - } \\
\text { Placebo + } \\
\text { Double } \\
\text { Blind }\end{array}$ & $\begin{array}{l}10 \text { sets of 10reps of peak } \\
\text { isometric force jumps } \\
4000 \text { IU of Vitamin D3 or } \\
\text { Placebo/Day }\end{array}$ & 28 Days & $\begin{array}{l}\text { Vitamin D vs Placebo: (1) } \downarrow \\
\text { ALT and AST(2) Less of a } \downarrow \\
\text { in peak power output }\end{array}$ \\
\hline
\end{tabular}

performance benefits might be limited to individuals with significant vitamin D deficiency [Table 3].

\section{Vitamin D and testosterone}

Testosterone is an endogenous hormone important for muscular adaptations to training. Naturally low testosterone levels in young men have been linked to decreases in protein anabolism, strength, beta-oxidation, and an increase in adipose deposition [57]. Thus, athletes endeavour to optimize natural androgenic production. A recent cross-sectional study done on 2299 older men $(62 \pm 11$ years of age) showed that $25(\mathrm{OH}) \mathrm{D}$ levels

Table 3 Vitamin D correlation and intervention studies on force \& power production

\begin{tabular}{|c|c|c|c|c|c|c|c|}
\hline Author & $\begin{array}{l}\text { Reference } \\
\#\end{array}$ & Population & $\begin{array}{l}\text { Subjects/ } \\
\text { Specimens }\end{array}$ & $\begin{array}{l}\text { Type of } \\
\text { Study }\end{array}$ & Intervention & Duration & Results \\
\hline $\begin{array}{l}\text { Ceglia et } \\
\text { al. } 2013\end{array}$ & {$[55]$} & Elderly & $\begin{array}{l}21 \text { Mobility- } \\
\text { Limited Women } \\
\text { (age } 265 \text { ) with } \\
25\{\mathrm{OH}) \mathrm{D} \text { levels } \\
\text { of } 225 \mathrm{to} \\
60 \mathrm{nmol} / \mathrm{L}\end{array}$ & $\begin{array}{l}\text { Intervention } \\
\text { - RCT- } \\
\text { Placebo + } \\
\text { Double } \\
\text { Blind }\end{array}$ & $\begin{array}{l}4000 \text { IU/Day of Vitamin D or } \\
\text { Placebo }\end{array}$ & 4 Months & $\begin{array}{l}\text { Vitamin D3 supplementation } \uparrow \\
\text { intramyonuclear VDR } \\
\text { concentration by } 30 \% \text { and } \\
\text { increased muscle fiber size by } \\
10 \% \text { in older, mobility-limited, } \\
\text { vitamin D- insufficient women. }\end{array}$ \\
\hline $\begin{array}{l}\text { Close et } \\
\text { al. } 2013\end{array}$ & {$[56]$} & Athletes & $\begin{array}{l}10 \text { Male } \\
\text { Professional } \\
\text { Soccer Players }\end{array}$ & $\begin{array}{l}\text { Correlation } \\
+ \\
\text { Intervention } \\
-\mathrm{RCT}\end{array}$ & $\begin{array}{l}5000 \text { IU/Day of Vitamin D3 or } \\
\text { Placebo }\end{array}$ & 8 Weeks & $\begin{array}{l}\text { Vitamin D vs Placebo: (1) } \uparrow \\
\text { Serum } 25 \text { hydroxyvitamin D (2) } \\
\uparrow \text { in Vertical Jump (3) Faster } \\
10 \text { m sprint times }\end{array}$ \\
\hline $\begin{array}{l}\text { Close et } \\
\text { al. } 2013\end{array}$ & [10] & Athletes & $\begin{array}{l}30 \text { Club-Level } \\
\text { Athletes from UK }\end{array}$ & $\begin{array}{l}\text { Intervention } \\
\text { - RCT }\end{array}$ & $\begin{array}{l}\text { Three Groups: Placebo, } \\
\text { 20,000IU/Week, or 40,000 IU/ } \\
\text { week of Oral Vitamin D3 } \\
\text { (Performance Testing: 1-RM } \\
\text { Bench Press, 1-RM Leg Press } \\
\text { and Vertical Jump) }\end{array}$ & 12 Weeks & $\begin{array}{l}\text { Both } 20,000 \mathrm{IU} \text { and } 40,000 \mathrm{IU} \text { of } \\
\text { Vitamin } \mathrm{D} 3 \uparrow 25(\mathrm{OH}) \mathrm{D} \text { over }> \\
50 \mathrm{nmol} / \mathrm{L}, \text { but had no effect } \\
\text { on any performance } \\
\text { measurement }\end{array}$ \\
\hline $\begin{array}{l}\text { Fitzgeral } \\
\text { et al. } \\
2014\end{array}$ & [41] & Athletes & $\begin{array}{l}52 \text { Caucasian } \\
\text { Competitive Ice } \\
\text { Hockey Players } \\
\text { (age } 20.1 \pm 1.5 \text { ) } \\
\text { (V02max } 54.6 \pm \\
\text { 4.3) }\end{array}$ & $\begin{array}{l}\text { Cross- } \\
\text { sectional }\end{array}$ & $\begin{array}{l}\text { Performance Testing: Maximal } \\
\text { Oxygen Uptake (V02peak), Max } \\
\text { Heart Rate (HR), Peak RER, Total } \\
\text { Exercise Time }\end{array}$ & $\begin{array}{l}1 \text { Month } \\
\text { Recruiting } \\
\text { Phase } \\
\text { During Off- } \\
\text { Season (May } \\
\text { to June) }\end{array}$ & $\begin{array}{l}\text { All Athletes had } 25(\mathrm{OH}) \mathrm{D} \text { Levels } \\
£ 65.0 \mathrm{ng} / \mathrm{mL}, 37.7 \% \text { of the } \\
\text { Athletes had } 25(\mathrm{OH}) \mathrm{D} \text { levels of } \\
<32 \mathrm{ng} / \mathrm{mL} \& 25(\mathrm{OH}) \text { D status } \\
\text { was not significantly associated } \\
\text { with any parameter measured }\end{array}$ \\
\hline $\begin{array}{l}\text { Forney } \\
\text { et al. } \\
2014\end{array}$ & {$[42]$} & $\begin{array}{l}\text { Active } \\
\text { College } \\
\text { Students }\end{array}$ & $\begin{array}{l}39 \text { Phyiscally } \\
\text { Active College } \\
\text { Students(20 } \\
\text { Males, } 19 \\
\text { Females) }\end{array}$ & Correlation & $\begin{array}{l}25(\mathrm{OH}) \mathrm{D} \text { Levels of } 20.97 \pm \\
1.97 \mathrm{ng} / \mathrm{mL}(\mathrm{N}=20) \text { or } 44.15 \pm \\
2.17 \mathrm{ng} / \mathrm{mL}(\mathrm{N}=19) \text { - Primary } \\
\text { Outcomes: BMl, \% Body Fat, } \\
\text { Resting Metabolic Rate, } \\
\text { Maximal Oxygen Uptake } \\
\text { (V02max), Power Output } \\
\text { (Watts), and Muscle Strength }\end{array}$ & 14 Days & $\begin{array}{l}\text { Significant positive relationship } \\
\text { seen between V02max and } \\
25(\mathrm{OH}) \mathrm{D} \text { \& Significant negative } \\
\text { relationship seen between BMl } \\
\text { and } 25(\mathrm{OH}) \mathrm{D}\end{array}$ \\
\hline
\end{tabular}


correlated with testosterone and androgen levels in men [58]. Low testosterone, or hypogonadism, was identified in $18 \%$ of the participants, and these men had significantly lower mean $25(\mathrm{OH}) \mathrm{D}$ levels than the rest of the population. Furthermore, only $11.4 \%$ of the sample had sufficient levels of vitamin $\mathrm{D}$.

Additionally a 12-month, double-blind, randomized control trial in 54 non-diabetic males demonstrated that the group receiving $3332 \mathrm{IU} /$ day of vitamin D had a significant increase in circulating 25-hydroxyvitamin D, total testosterone, bioactive testosterone, and free testosterone levels [59]. These findings support the notion that elevating $25(\mathrm{OH}) \mathrm{D}$ levels may augment testosterone production in non-diabetic male subjects, which indicates that vitamin D supplementation might have ergogenic potential through the enhancement of endogenous testosterone production. More research is required in order to investigate this potential role of vitamin $\mathrm{D}$ and testosterone levels in various study populations [Table 4].

The specific mechanism of action of $25(\mathrm{OH}) \mathrm{D}$ on testosterone in men could potentially be related to two processes: inhibited testosterone aromatization and enhanced androgen binding. Evidence for both of these mechanisms comes from animal models. Specifically, higher 25(OH)D levels inhibit gonadal aromatization of testosterone in VDR knockout mice [60]. Secondly, VDR and vitamin D metabolizing enzymes have been located in human and rat testis and have been shown to enhance the affinity of androgen binding receptors [57, 61, 62]. This effect increases the rate at which androgens can bind to testosterone-producing glands resulting in higher concentrations of steroid hormones, leading to an increase in skeletal muscle hypertrophy, strength and power output $[63,64]$.

\section{Sources}

\section{Sunlight}

Humans acquire vitamin D from two different sources, endogenous production after sun exposure, or via the diet (from food or supplementation). Unlike the metabolism of dietary vitamin $\mathrm{D}$, the synthesis of vitamin $\mathrm{D}_{3}$ by the skin is a non-enzymatic biological process [65]. Once the skin is exposed to the Sun's ultraviolet B (UVB) radiation, it then converts stored 7-dehydrocholesterol into circulating vitamin $\mathrm{D}_{3}, 25(\mathrm{OH}) \mathrm{D}$ [29] and other isomers [66]. The amount of UVB exposure determines the amount and the specific isomers of vitamin $\mathrm{D}_{3}$ that will form $[66,67]$. The recommended dosage of sunlight exposure during the summer is five to $20 \mathrm{~min}$ per day to $5.0 \%$ of exposed skin at a UVB radiation of $290-315 \mathrm{~nm}[68,69]$ two to three times a week [70]. Additionally, it has been shown that $15 \mathrm{~min}$ of adequate (290-315 $\mathrm{nm}$ ) UVB exposure during the summer months in a bathing suit can produce 10,000 to $20,000 \mathrm{IU}$ of vitamin $\mathrm{D}_{3}$ [71]. However, multiple factors can affect the rate and synthesis of vitamin $\mathrm{D}_{3}$ [Table 5] $[25,66,72-74]$.

\section{Diet}

Vitamin $\mathrm{D}$ derived from diet and supplementation comes in two forms, the plant-based vitamin $\mathrm{D}_{2}$ (ergocalciferol), and the more bioavailable mammal and fish source, vitamin $\mathrm{D}_{3}$ (cholecalciferol) [75]. Vitamin $\mathrm{D}$ can be found in various food products [Fig. 2] [76], such as fortified cereals and milk, natural foods like salmon, or through various vitamin $\mathrm{D}$ analogues produced synthetically in a laboratory [Table 6] [18, 76]. Both sources are considered prohormone compounds, capable of increasing circulating $25(\mathrm{OH}) \mathrm{D}$, after they have been converted by the enzymatic reactions described earlier.

\section{Dosage for optimal performance}

Both $D_{2}$ and $D_{3}$ are capable of increasing plasma 25(OH)D concentration, but vitamin $\mathrm{D}_{3}$ might be more effective than vitamin $\mathrm{D}_{2}[75,77,78]$. When compared to vitamin $D_{3}$, vitamin $D_{2}$ is less stable, less bioavailable with increasing age, and it has been shown in multiple clinical studies that the amount of vitamin $\mathrm{D}_{2}$ absorbed is significantly lower than with vitamin $\mathrm{D}_{3}$. Furthermore, vitamin $D_{2}$ has a lower affinity to VDRs [54, 75, 77-79] and a higher rate of deactivation once hydroxylated in

Table 4 Vitamin D correlation, in vivo and intervention studies testosterone

\begin{tabular}{|c|c|c|c|c|c|c|c|}
\hline Author & $\begin{array}{l}\text { Reference } \\
\#\end{array}$ & Population & $\begin{array}{l}\text { Subjects/ } \\
\text { specimens }\end{array}$ & $\begin{array}{l}\text { Type of } \\
\text { study }\end{array}$ & Intervention & Duration & Results \\
\hline $\begin{array}{l}\text { Wehr } \\
\text { et al. } \\
2010\end{array}$ & [53] & Elderly & $\begin{array}{l}\text { 2,299Caucasian } \\
\text { Male Subjects } \\
\text { (age S2 } \pm 11 \text { ) }\end{array}$ & $\begin{array}{l}\text { Cross- } \\
\text { sectional }\end{array}$ & - & - & $\begin{array}{l}\text { Positive correlation seen between } 25(\mathrm{OH}) \mathrm{D} \\
\text { levels and Testosterone and Androgen Levels }\end{array}$ \\
\hline $\begin{array}{l}\text { Pilz, } \\
\text { Frisch \& } \\
\text { Koertke } \\
2011\end{array}$ & [59] & $\begin{array}{l}\text { Healthy } \\
\text { Males }\end{array}$ & $\begin{array}{l}54 \text { Healthy } \\
\text { Overweight Males } \\
\text { (age range 20-49) }\end{array}$ & $\begin{array}{l}\text { Intervention } \\
-\mathrm{RCT}\end{array}$ & $\begin{array}{l}3332 \text { IU/Day of } \\
\text { Vitamin Dor } \\
\text { Placebo }\end{array}$ & $\begin{array}{l}12 \\
\text { Months }\end{array}$ & $\begin{array}{l}\text { Significant } \uparrow \text { in } 25(\mathrm{OH}) \mathrm{D} \text {, Total Testosterone, } \\
\text { Bioactive Testosterone and Free Testosterone } \\
\text { Positive relationship between higher }\end{array}$ \\
\hline $\begin{array}{l}\text { Kinuta } \\
\text { et al. } \\
2014\end{array}$ & {$[60]$} & Rat Model & $\begin{array}{l}\text { VDR Knockout } \\
\text { Mice }\end{array}$ & $\begin{array}{l}\text { Intervention } \\
\text { - In Vivo }\end{array}$ & $\begin{array}{l}\text { VDR Knockout } \\
\text { Mice - Disruption } \\
\text { of VDR gene }\end{array}$ & - & $\begin{array}{l}25(\mathrm{OH}) \mathrm{D} \text { levels and inhibition of gonadal } \\
\text { armoatization of testosterone }\end{array}$ \\
\hline
\end{tabular}


Table 5 Factors affecting the rate and synthesis of endogenously produced vitamin D

Seasonal Variations in UVB Exposure
Living at Latitudes ( $32-42^{\circ} \mathrm{N}$ or S) That Are Further Away From The
Equator
Higher Altitudes
Cloudy Climates
Thick Ozone Layers due to Pollution
Darker Skin Pigmentation (higher melanin [natural sun-block] levels)
Higher Adipose Tissue (obesity)
Older Age
Utilization of Sun-block

the kidney due to side-chain variations [77]. Lastly, an epidemiological study during the winter months in Dunedin, New Zealand investigated the effects of $1000 \mathrm{IU} /$ day of either vitamin $D_{2}$ or vitamin $D_{3}$ supplementation over a 25 -week period in 95 healthy, adult participants (18-50 years old) [78]. The participants who received the vitamin $D_{2}$ supplement had a larger decrease in serum $25(\mathrm{OH}) \mathrm{D}(74 \mathrm{nmol} / \mathrm{L}$ to $50 \mathrm{nmol} / \mathrm{L})$ levels than those who took vitamin $\mathrm{D}_{3}(80 \mathrm{nmol} / \mathrm{L}$ to $72 \mathrm{nmol} / \mathrm{L})$ [78]. However, both results show that $1000 \mathrm{IU} /$ day of vitamin $D$ was inadequate to increase serum $25(\mathrm{OH}) \mathrm{D}$ concentrations and actually caused a decline with both isoforms.

With vitamin $\mathrm{D}_{3}$ proving more efficacious, the optimal dosage varies depending on the individual and the institution providing the guidelines. The Institute of Medicine (IOM) recommends 400-800 IU/day for children, adults and individuals $>70$ years of age to maintain serum vitamin $\mathrm{D}$ at $>50 \mathrm{nmol} / \mathrm{L}[11,80,81]$. Alternatively, the Endocrine Society (ES) recommends a slightly higher intake, with dosages of 400-1000 IU/ day for infants, 600-1000 IU/day for children, and 1500-2000 IU/day for adults in order to maintain adequate serum vitamin $\mathrm{D}$ concentrations of $75 \mathrm{nmol} / \mathrm{L}$ [82]. These recommendations correspond with a review in 2004 [83], stating that $70 \mathrm{nmol} / \mathrm{L}$ is the lowest desirable serum concentration to prevent adverse health effects. Other recommendations have suggested optimal levels may be 90 to greater than $120 \mathrm{nmol} / \mathrm{L}[86,87]$, based on estimations made from that of levels seen in individuals inhabiting very sunlight-rich environments [84] and/or have shown optimal lower-extremity function [85].

The definitions of hypovitaminosis or hypervitaminosis are more controversial. The IOM defines inadequate stores of $25(\mathrm{OH}) \mathrm{D}$ as $30-50 \mathrm{nmol} / \mathrm{L}$, and deficiency as $25(\mathrm{OH}) \mathrm{D}<30 \mathrm{nmol} / \mathrm{L}$ [88], and sets the upper limit of dietary intake of vitamin D to $4000 \mathrm{IU} /$ day [69]. The ES on the other hand, defines vitamin $\mathrm{D}$ deficiency at levels of $25(\mathrm{OH}) \mathrm{D}<50 \mathrm{nmol} / \mathrm{L}$, insufficiency as $25(\mathrm{OH}) \mathrm{D}$ between 51 to $74 \mathrm{nmol} / \mathrm{L}$ [89], and sets the upper limit of dietary intake of vitamin D to 10,000 IU/day [19]. However, recent reviews have suggested that this is more of a theoretical concern $[72,83,84,90]$. The optimal vitamin D dosage and level are clearly controversial [88, 91]. Furthermore, the optimal levels needed for athletic performance have not yet been determined. Growing evidence has supported that 600-800 IU/day may not be sufficient for optimal levels of vitamin D, especially for the athletic population [92], since serum $25(\mathrm{OH}) \mathrm{D}$ concentrations

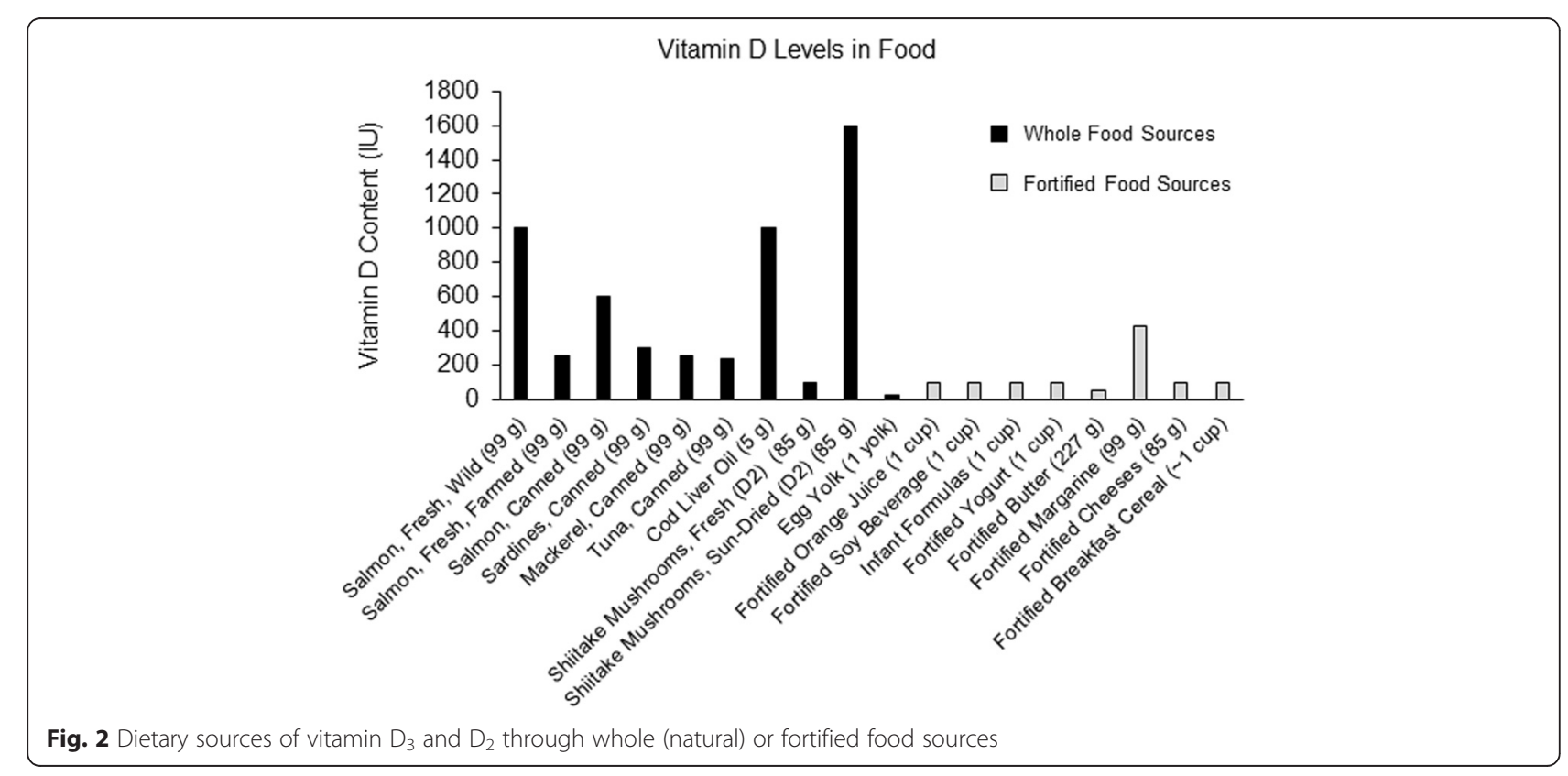


Table 6 Vitamin D sources from pharmacological analogs

\begin{tabular}{|c|c|c|c|}
\hline Pharmacological supplements & Serving size & Type of vitamin D & Vitamin D (1U) \\
\hline \multicolumn{4}{|l|}{ Prescription } \\
\hline Pill & 1 pill & D2 or D3 & 50,000 \\
\hline Liquid & $1 \mathrm{ml}$ & D2 or D3 & 8000 \\
\hline \multicolumn{4}{|l|}{ Over The Counter } \\
\hline Multi-Vitamin & 1 serv & D2 or D3 & 1000 \\
\hline 400 IU Pill & 1 pill & D2 or D3 & 400 \\
\hline 800 IU Pill & 1 pill & D2 or D3 & 800 \\
\hline 1000 IU Pill & 1 pill & D2 or D3 & 1000 \\
\hline 2000 IU Pill & 1 pill & D2 or D3 & 2000 \\
\hline 5000 IU Pill & 1 pill & $\mathrm{D} 2$ or D3 & 5000 \\
\hline
\end{tabular}

greater than $100 \mathrm{nmol} / \mathrm{L}$ have been proposed to be optimal for lower body skeletal muscle function [85] and low vitamin $\mathrm{D}$ levels are linked to increased bone turnover, increasing the risk of stress fractures [93]. It has been shown that it takes roughly 2000 to $5000 \mathrm{IU} /$ day of vitamin D from all available sources in order to optimize bone health by maintaining serum $25(\mathrm{OH}) \mathrm{D}$ levels of 75 to $80 \mathrm{nmol} / \mathrm{L}$ $[84,85,94,95]$. Furthermore, this dosage would be unattainable from natural UVB exposure during the months of October to April when residing in latitudes of 42.2 to $52^{\circ} \mathrm{N}$ [96] which is indicated by the high prevalence of vitamin $\mathrm{D}$ deficient indoor and outdoor athletes in a multitude of disciplines [24, 97-99]. Lastly, studies that have shown to improve athletic prowess utilize dosages higher than $3000 \mathrm{IU} /$ day, but none have yet to reach levels greater than $100 \mathrm{nmol} / \mathrm{L}$. Thus, it remains unclear, but athletes may benefit from $25(\mathrm{OH}) \mathrm{D}$ levels $\geq 100 \mathrm{nmol} / \mathrm{L}$ in order to increase skeletal muscle function and reduce the risk of stress fractures.

However, no study to date has looked at the effects of vitamin D supplementation and skeletal muscle function in the athletic population with $25(\mathrm{OH}) \mathrm{D}$ levels of $\geq 100 \mathrm{nmol} / \mathrm{L}$ [36]. Additionally, the previous performance intervention studies presented in this review supplemented with dosages far greater than the recommended dosages of 600-2000 IU/day (e.g., 5000 IU/day of $\mathrm{D}_{3}$ ) and $1000 \mathrm{IU} /$ day of vitamin $\mathrm{D}_{3}$ during the winter months is not enough to prevent a decline in serum 25(OH)D stores [78].

\section{Toxicity \& hypercalcemia}

Although it has been reported that vitamin $\mathrm{D}$ toxicity might occur with dosages of $\geq 10,000$ IU/day for an extended period [71, 84], producing adverse effects like hypercalcemia, the level of vitamin $\mathrm{D}$ causing toxicity is unclear $[71,100]$, and due to ethical reasons, no prospective studies have analyzed the effect of vitamin D intoxication in humans. Recently, an accidental overdose of 2,000,000 IU of vitamin $\mathrm{D}_{3}$ in two elderly patients did not cause adverse effects and only elevated blood calcium levels slightly [101]. More importantly, adverse effects have only been reported at serum concentrations of 25(OH)D above $200 \mathrm{nmol} / \mathrm{L}$, which would take daily dosages of 40,000 IU or more of vitamin D to achieve [84], and serum concentrations of $25(\mathrm{OH}) \mathrm{D}$ of $<140 \mathrm{nmol} / \mathrm{L}$ have not been correlated with hypercalcemia. 1,25-dihydroxyvitamin D works synergistically with calcium and allows it to be absorbed from the gastrointestinal tract and stimulates mature osteoblasts to produce receptor activator nuclear factor-kB ligand (RANKL) [102]. RANKL in turn stimulates mineralization and bone resorption via osteoclastogenesis. Increased levels of $25(\mathrm{OH}) \mathrm{D}$ can accelerate this process, causing a rise in calcium concentration in the blood, a higher absorption rate of calcium by the kidneys, and could potentially lead to kidney stones and/or potential vascular calcification [103].

\section{Vitamin K}

Any discussion of vitamin $\mathrm{D}$ toxicity merits mention of vitamin K. As with calcium, vitamin K works synergistically with vitamin D to regulate bone resorption, activation and distribution [104]. Vitamin K carboxylates the newly-formed ostecalcin proteins that are produced in mature bone cells and are tightly regulated by vitamin D [105]. Once the protein is carboxylated, it interacts with calcium ions in bone tissue [106] and has a significant effect on bone mineralization, formation, the prevention of bone loss, and potentially the stoppage of fractures in women [105, 107-111]. However, when levels of vitamin $\mathrm{K}$ are inadequate, the ostecalcin production is not suppressed [109]. This situation facilitates a build-up of uncarboxylated (inactive) ostecalcin proteins in bone, leading to a potential increase in calcium release from bone and the deposition of calcium into soft tissues (causing arterial calcification) $[112,113]$. Thus, vitamin $\mathrm{D}_{3}$ toxicity might occur only in the absence of sufficient vitamin K stores. 
Recommended dosages of vitamin $\mathrm{K}$ range from 50 $\mathrm{mcg}$ to $1000 \mathrm{mcg}$ [108]. However, these recommendations are controversial since vitamin $\mathrm{K}$ stores are rapidly depleted without constant supply [114] and like vitamin $D$, vitamin $K$ also has two variants: $K_{1}$ and $K_{2}$. Sources of vitamin $\mathrm{K}$ can be found in pharmacological analogues and naturally in the diet. Vitamin $K_{1}$, the most abundant form found in an individual's diet [115], is high in green leafy cruciferous vegetables, fruits, various vegetable oils and beans [114]. Vitamin $K_{2}$, the more bioavailable form of vitamin K [114], comes in a variety of fish, offal, meat, dairy products, fermented cheese (e.g., blue cheese), and fermented products like natto (fermented soybeans, a Japanese delicacy) [116].

Both forms play different roles in the body [117], but the IOM has set the recommended dietary intake only for the $K_{1}$ isoform $(90 \mathrm{mcg} /$ day for women and $120 \mathrm{mcg} /$ day for men), with no upper limit, and has yet to set any dietary recommendation for vitamin $K_{2}$ [114]. Specifically, vitamin $K_{1}$ has a key role in the carboxylation of various blood clotting proteins, where vitamin $K_{2}$ is essential for the carboxylation and activation of osteocalcin and matrix Gla protein (MGP) (an essential protein needed to prevent soft tissue calcification) [118]. More importantly, one of the vitamin $K_{2}$ variants, MK-4, is more effective at mitigating osteoclast formation and the negative health effects of vitamin $\mathrm{D}$ overdose $[114,115]$. Furthermore, $10 \mathrm{mg} /$ day $(10,000 \mathrm{mcg})$ of synthetic vitamin $K_{1}$ (phytonadione, sold as Konakion ${ }^{\circledR}$ [119]) has been shown to be beneficial for elite female marathon runners by increasing bone formation and preventing bone loss [120] and mega-doses of $45 \mathrm{mg} /$ day $(45,000 \mathrm{mcg})$ of MK-4 in combination with vitamin $\mathrm{D}_{3}$ could prevent osteoporosis in postmenopausal women $[102,109]$. Thus, although MK-4 might have the greatest effect on carboxylation of osteocalcin, both vitamin $K_{1}$ and $K_{2}$ interact with each other in order to optimize bone health and are essential to the human body. Further research in athletic populations should focus on the optimal dosage for vitamin $\mathrm{D}_{3}$ in combination with vitamin $\mathrm{K}$.

\section{Conclusion}

In summary, an interesting theme has emerged from animal studies that supraphysiological dosages of vitamin $D_{3}$ have potential ergogenic effects on the human metabolic system and lead to multiple physiological enhancements. These dosages could increase aerobic capacity, muscle growth, force and power production, and a decreased recovery time from exercise. These dosages could also improve bone density. However, both deficiency (12.5 to $50 \mathrm{nmol} / \mathrm{L})$ and high levels of vitamin D (>125 nmol/L) can have negative side effects, with the potential for an increased mortality [121]. Thus, maintenance of optimal serum levels between 75 to $100 \mathrm{nmol} / \mathrm{L}[11,86]$ and ensuring adequate amounts of other essential nutrients including vitamin $\mathrm{K}$ are consumed, is key to health and performance. Coaches, medical practitioners, and athletic personnel should recommend their patients and athletes to have their plasma 25(OH)D measured, in order to determine if supplementation is needed. Based on the research presented on recovery, force and power production, 4000$5000 \mathrm{IU} /$ day of vitamin $\mathrm{D}_{3}$ in conjunction with a mixture of $50 \mathrm{mcg} /$ day to $1000 \mathrm{mcg} /$ day of vitamin $K_{1}$ and $K_{2}$ seems to be a safe dose and has the potential to aid athletic performance. Lastly, no study in the athletic population has increased serum 25(OH)D levels past $100 \mathrm{nmol} / \mathrm{L}$, (the optimal range for skeletal muscle function) using doses of 1000 to $5000 \mathrm{IU} /$ day. Thus, future studies should test the physiological effects of higher dosages (5000 IU to 10,000 IU/day or more) of vitamin $\mathrm{D}_{3}$ in combination with varying dosages of vitamin $K_{1}$ and vitamin $K_{2}$ in the athletic population to determine optimal dosages needed to maximize performance.

\section{Competing interests}

The authors declare that they have no competing interests.

\section{Authors' contributions}

DTD formulated the idea for the literature review, acquired the research articles, interpreted the literature presented, and drafted the initial manuscript; BD and MSK helped advise the direction of the manuscript, the interpretation of literature presented, and thoroughly edited/rewrote the manuscript to prepare for final submission. Each author read and approved the final manuscript prior to submission.

\section{Author details}

${ }^{1}$ Simon Fraser University, Biomedical Physiology and Kinesiology (BPK), 8888 University Drive - Burnaby, Vancouver, BC V5A 156, Canada. ${ }^{2}$ UBC

Environmental Physiology Laboratory, School of Kinesiology, University of British Columbia, Vancouver, BC, Canada. ${ }^{3}$ Providence Medical Research Center, Providence Sacred Heart Medical Center and Children's Hospital, Research Discovery Lab, Spokane, WA 99204, USA.

Received: 1 April 2015 Accepted: 9 August 2015

Published online: 19 August 2015

\section{References}

1. McCollum E, Simmonds N, Becker J, Shipley P. An experimental demonstration of the existence of a vitamin which promotes calcium deposition. J Biol Chem. 1922;1922:293-8.

2. Jones G. Metabolism and biomarkers of vitamin D. Scand J Clin Lab Invest. 2012;72(Suppl 243):7-13.

3. Wang T-T, Tavera-Mendoza LE, Laperriere D, Libby E, MacLeod NB, Nagai $Y$, et al. Large-scale in silico and microarray-based identification of direct 1,25-dihydroxyvitamin D3 target genes. Mol Endocrinol. 2005;19:2685-95.

4. Smith DT, Broughton KS, Larson-meyer DE. Vitamin D status and biomarkers of inflammation in runners. 2012;3:35-42.

5. Alvarez-Díaz S, Valle N, García JM, Peña C, Freije JMP, Quesada V, et al. Cystatin $D$ is a candidate tumor suppressor gene induced by vitamin $D$ in human colon cancer cells. J Clin Invest. 2009;119:2343-58.

6. Dhesi JK, Jackson SHD, Bearne LM, Moniz C, Hurley MV, Swift CG, et al. Vitamin D supplementation improves neuromuscular function in older people who fall. Age Ageing. 2004;33:589-95.

7. Reddy Vanga S, Good M, Howard PA, Vacek JL. Role of vitamin D in cardiovascular health. Am J Cardiol. 2010;106:798-805. 
8. Sukumar D, Shapses SA, Schneider SH. Vitamin D supplementation during short-term caloric restriction in healthy overweight/obese older women: effect on glycemic indices and serum osteocalcin levels. Mol Cell Endocrinol. 2015;410:1-5.

9. Schoenmakers I, Francis RM, McColl E, Chadwick T, Goldberg GR, Harle C, et al. Vitamin D supplementation in older people (VDOP): Study protocol for a randomised controlled intervention trial with monthly oral dosing with $12,000 \mathrm{IU}, 24,000 \mathrm{IU}$ or $48,000 \mathrm{IU}$ of vitamin $\mathrm{D}_{3}$. Trials. 2013;14:299.

10. Close GL, Leckey J, Patterson M, Bradley W, Owens DJ, Fraser WD, et al. The effects of vitamin $D(3)$ supplementation on serum total $25[\mathrm{OH}] \mathrm{D}$ concentration and physical performance: a randomised dose-response study. Br J Sports Med. 2013;47:692-6.

11. Bendik I, Friedel A, Roos FF, Weber P, Eggersdorfer M. Vitamin D: a critical and essential micronutrient for human health. Front Physiol. 2014;5:248.

12. Grudet C, Malm J, Westrin A, Brundin L. Suicidal patients are deficient in vitamin D, associated with a pro-inflammatory status in the blood. Psychoneuroendocrinology. 2014;50C:210-9.

13. Polak MA, Houghton LA, Reeder Al, Harper MJ, Conner TS. Serum 25-hydroxyvitamin D concentrations and depressive symptoms among young adult men and women. Nutrients. 2014;6:4720-30.

14. Chei CL, Raman P, Yin Z-X, Shi X-M, Zeng Y, Matchar DB. Vitamin D levels and cognition in elderly adults in China. J Am Geriatr Soc. 2014;62(11):2125-9.

15. Holick MF. Vitamin D: its role in cancer prevention and treatment. Prog Biophys Mol Biol. 2006:92:49-59.

16. Guillot X, Prati C, Wendling D. Vitamin D and spondyloarthritis. Expert Rev Clin Immunol. 2014;10:1581-9.

17. Welch TR, Bergstrom WH, Tsang RC. Vitamin D-deficient rickets: the reemergence of a once-conquered disease. J Pediatr. 2000;137:143-5.

18. Bikle DD. Vitamin D metabolism, mechanism of action, and clinical applications. Chem Biol. 2014;21:319-29.

19. Ogan D, Pritchett K. Vitamin D and the athlete: risks, recommendations, and benefits. Nutrients. 2013;5:1856-68.

20. Sato Y, Iwamoto J, Kanoko T, Satoh K. Low-dose vitamin D prevents muscular atrophy and reduces falls and hip fractures in women after stroke: a randomized controlled trial. Cerebrovasc Dis. 2005;20:187-92.

21. Glerup H, Mikkelsen K, Poulsen L, Hass E, Overbeck S, Andersen H, et al. Hypovitaminosis D myopathy without biochemical signs of osteomalacic bone involvement. Calcif Tissue Int. 2000:66:419-24.

22. Pfeifer M, Begerow B, Minne H. Vitamin D and muscle function. Osteoporos Int. 2002;3:187-94.

23. Macdougall JD, Hicks AL, Macdonald JR, Mckelvie RS, Green HJ, Smith KM. Muscle performance and enzymatic adaptations to sprint interval training. J Appl Physiol. 1998;84:2138-142.

24. Farrokhyar F, Tabasinejad R, Dao D, Peterson D, Ayeni O, Hadioonzadeh $R$, et al. Prevalence of vitamin $D$ inadequacy in athletes: A systematicreview and meta-analysis. Sport Med. 2014;5:365-78.

25. Calvo M, Whiting S. Prevalence of vitamin D insufficiency in Canada and the United States: importance to health status and efficacy of current food fortification and dietary supplement use. Nutr Rev. 2003;61:107-13.

26. Hossein-nezhad A, Holick MF. Vitamin D for health: a global perspective. Mayo Clin Proc. 2013:88:720-55

27. Schlögl M, Holick MF. Vitamin D and neurocognitive function. Clin Interv Aging. 2014;9:559-68

28. Holick MF. Vitamin D: evolutionary, physiological and health perspectives. Curr Drug Targets. 2011;12:4-18.

29. Prosser DE, Jones G. Enzymes involved in the activation and inactivation of vitamin D. Trends Biochem Sci. 2004;29:664-73.

30. Bischoff H, Borchers M, Gudat F, Duermueller U, Theiler R, Stähelin H, et al. In situ detection of 1,25-dihydroxyvitamin D3 receptor in human skeletal muscle tissue. Histochem J. 2001:33:19-24.

31. Simpson R, Thomas G, Arnold A. Identification of 1,25-dihydroxyvitamin D3 receptors and activities in muscle*. J Biol Chem. 1985;260:8882-891.

32. Hamilton B. Vitamin d and athletic performance: the potential role of muscle. Asian J Sports Med. 2011;2:211-19.

33. Stockton KA, Mengersen K, Paratz JD, Kandiah D, Bennell KL. Effect of vitamin D supplementation on muscle strength: a systematic review and meta-analysis. Osteoporos Int. 2010;22:859-71.
34. Tomlinson PB, Joseph C, Angioi M. Effects of vitamin D supplementation on upper and lower body muscle strength levels in healthy individuals. A systematic review with meta-analysis. J Sci Med Sport. 2014;18(5):575-80

35. Beaudart C, Buckinx F, Rabenda V, Gillain S, Cavalier E, Slomian J, et al. The effects of vitamin D on skeletal muscle strength, muscle mass and muscle power: A systematic review and meta-analysis of randomized controlled trials. J Clin Endocrinol Metab. 2014;99:4336-345.

36. Von Hurst PR, Beck KL. Vitamin D and skeletal muscle function in athletes. Curr Opin Clin Nutr Metab Care. 2014;17:539-45.

37. Gregory SM, Parker BA, Capizzi JA, Grimaldi AS, Clarkson PM, Moeckel-Cole $\mathrm{S}$, et al. Changes in vitamin D are not associated with changes in cardiorespiratory fitness. Clin Med Res. 2013;2:68.

38. Mowry DA, Costello MM, Heelan KA. Association among cardiorespiratory fitness, body fat, and bone marker measurements in healthy young females. J Am Osteopath Assoc. 2009;109(10):534-9

39. Ardestani A, Parker B, Mathur S, Clarkson P, Pescatello LS, Hoffman HJ, et al. Relation of vitamin D level to maximal oxygen uptake in adults. Am J Cardiol. 2011;107:1246-9.

40. Koundourakis NE, Androulakis NE, Malliaraki N, Margioris AN. Relation of vitamin D level to maximal oxygen uptake in adults. Am J Cardiol. 2011;107:1246-9.

41. Fitzgerald J, Peterson B, Warpeha J, Wilson P, Rhodes G, Ingraham S. Vitamin D status and VO2peak during a skate treadmill graded exercise test in competitive ice hockey players. J Strength Cond Res. 2014;28:3200-5.

42. Forney L, Earnest CC, Henagan T, Johnson L, Castleberry T, Stewart L. Vitamin D Status, Body Composition, and Fitness Measures in College-Aged Students. J Strength Cond Res. 2014;28:814-24.

43. Jastrzębski Z. Effect of vitamin D supplementation on the level of physical fitness and blood parameters of rowers during the 8-week high intensity training. Facicula Educ Fiz şi Sport. 2014;2:57-67.

44. Sugimoto H, Shiro Y. Diversity and substrate specificity in the structures of steroidogenic cytochrome P450 enzymes. Biol Pharm Bull. 2012;35:818-23.

45. D’Antona G, Lanfranconi F, Pellegrino MA, Brocca L, Adami R, Rossi R, et al. Skeletal muscle hypertrophy and structure and function of skeletal muscle fibres in male body builders. J Physiol. 2006;570(Pt 3):611-27.

46. Schoenfeld B. The mechanisms of muscle hypertrophy and their application to resistance training. J Strength Cond Res. 2010;24:2857-72.

47. Schoenfeld B. Does exercise-induced muscle damage play a role in skeletal muscle hypertrophy? J Strength Cond Res. 2012;26:1441-53.

48. Garcia LA, Ferrini MG, Norris KC, Artaza JN. 1,25(OH)2vitamin D3 enhances myogenic differentiation by modulating the expression of key angiogenic growth factors and angiogenic inhibitors in C2C12 skeletal muscle cells. J Steroid Biochem Mol Biol. 2013;133:1-11.

49. Garcia LA, King KK, Ferrini MG, Norris KC, Artaza JN. 1,25(OH)2vitamin D3 stimulates myogenic differentiation by inhibiting cell proliferation and modulating the expression of promyogenic growth factors and myostatin in C2C12 skeletal muscle cells. Endocrinology. 2011;152:2976-86.

50. Stratos I, Li Z, Herlyn P, Rotter R, Behrendt A-K, Mittlmeier T, et al. Vitamin D increases cellular turnover and functionally restores the skeletal muscle after crush injury in rats. Am J Pathol. 2013;182:895-904.

51. Lund D, Cornelison D. Enter the matrix: shape, signal and superhighway. FEBS J. 2013;280:4089-99.

52. Barker T, Schneider ED, Dixon BM, Henriksen VT, Weaver LK. Supplemental vitamin $\mathrm{D}$ enhances the recovery in peak isometric force shortly after intense exercise. Nutr Metab (Lond). 2013;10:69.

53. Ainbinder A, Boncompagni S, Protasi F, Dirksen RT. Role of mitofusin-2 in mitochondrial localization and calcium uptake in skeletal muscle. Cell Calcium. 2015;57:14-24

54. Todd JJ, Pourshahidi KL, McSorley EM, Madigan SM, Magee PJ. Vitamin D: Recent advances and implications for athletes. Sport Med. 2015;45:213-29.

55. Ceglia L, Niramitmahapanya S, da Silva MM, Rivas DA, Harris SS, Bischoff-Ferrari $\mathrm{H}$, et al. A randomized study on the effect of vitamin $D_{3}$ supplementation on skeletal muscle morphology and vitamin D receptor concentration in older women. J Clin Endocrinol Metab. 2013;98:E1927-35.

56. Close GL, Russell J, Cobley JN, Owens DJ, Wilson G, Fraser WD, et al. Assessment of vitamin $D$ concentration in non-supplemented professional athletes and healthy adults during the winter months in the UK: implications for skeletal muscle function. J Sports Sci. 2013;31:344-53. 
57. Mauras N, Hayes V, Welch S, Rini A, Helgeson K, Dokler M, Veldhuis JD, Urban RJ. Testosterone deficiency in young men: Marked alterations in whole body protein kinetics, strength, and adiposity*. J Clin Endocrino Metab. 1998:83:1886-892.

58. Wehr E, Pilz S, Boehm B, März W, Obermayer-Pietsch B. Association of vitamin D status with serum androgen levels in men. Clin Endocrinol (Oxf). 2010;73:243-8.

59. Pilz S, Frisch S, Koertke H, Kuhn J, Dreier J, Obermayer-Pietsch B, et al. Effect of vitamin D supplementation on testosterone levels in men. Horm Metab Res. 2011;43:223-5.

60. Kinuta K, Tanaka H, Moriwake T, Aya K, Kato S, Seino Y. Vitamin D is an important factor in estrogen biosynthesis of both female and male gonads*. Endocrinology 200AD, 141:1317-324.

61. Blomberg Jensen M, Nielsen JE, Jørgensen A, Rajpert-De Meyts E, Kristensen DM, Jørgensen N, et al. Vitamin D receptor and vitamin D metabolizing enzymes are expressed in the human male reproductive tract. Hum Reprod. 2010;25:1303-11.

62. Blomberg Jensen $M$, Dissing S. Non-genomic effects of vitamin D in human spermatozoa. Steroids. 2012;77:903-9.

63. Herbst KL, Bhasin S. Testosterone action on skeletal muscle. Curr Opin Clin Nutr Metab Care. 2004;7:271-7.

64. Urban RJ. Growth hormone and testosterone: Anabolic effects on muscle. Horm Res Pædiatrics. 2011;76:81-3.

65. Holick M, MacLaughlin J, Clark M, Holick S, Potts J, Anderson R, et al. Photosynthesis of previtamin D3 in human skin and the physiologic consequences. Am Assoc Adv Sci. 1980;210:203-05.

66. Webb AR. Who, what, where and when-influences on cutaneous vitamin D synthesis. Prog Biophys Mol Biol. 2006;92:17-25.

67. Gilchrest B. Sun exposure and vitamin D sufficiency. Am J Clin Nutr. 2008:88:570-7.

68. Lim HW, Gilchrest BA, Cooper KD, Bischoff-Ferrari HA, Rigel DS, Cyr WH, et al. Sunlight, tanning booths, and vitamin D. J Am Acad Dermatol. 2005;52:868-76.

69. Wolpowitz D, Gilchrest BA. The vitamin D questions: how much do you need and how should you get it? J Am Acad Dermatol. 2006;54:301-17.

70. Holick MF. Sunligth "D"ilemma: Risk of skin cancer or bone disease and muscle weakness. Lancet 2001:4-6.

71. Heaney RP. Vitamin D in health and disease. Clin J Am Soc Nephrol. 2008;3:1535-41.

72. Mithal A, Wahl DA, Bonjour J-P, Burckhardt P, Dawson-Hughes B, Eisman JA, et al. Global vitamin D status and determinants of hypovitaminosis D. Osteoporos Int. 2009;20:1807-20.

73. Walker N, Love TD, Baker DF, Healey PB, Haszard J, Edwards AS, et al. Knowledge and attitudes to vitamin $D$ and sun exposure in elite New Zealand athletes: a cross-sectional study. J Int Soc Sports Nutr. 2014;11:47.

74. Matsuoka LY, Wortsman J, Hollis BW. Use of topical sunscreen for the evaluation of regional synthesis of vitamin D3. J Am Acad Dermatol. 1990;22:772-5.

75. Tripkovic L, Lambert H, Hart K, Smith CP, Bucca G, Penson S, et al. Comparison of vitamin D2 and vitamin D3 supplementation in raising serum 25-hydroxyvitamin D status: a systematic review and meta-analysis. Am J Clin Nutr. 2012;95:1357-64.

76. Holick M. Vitamin D deficiency. N Engl J Med. 2007;357:266-81.

77. Houghton L,A, Vieth R. The case against ergocalciferol (vitamin D2) as a vitamin supplement. Am J Clin Nutr. 2006;84:694-7.

78. Logan VF, Gray AR, Peddie MC, Harper MJ, Houghton LA. Long-term vitamin D3 supplementation is more effective than vitamin D2 in maintaining serum 25-hydroxyvitamin D status over the winter months. Br J Nutr. 2013;109:1082-8.

79. Harris SS, Dawson-Hughes B. Plasma vitamin D and 25OHD responses of young and old men to supplementation with vitamin D3. J Am Coll Nutr. 2002;21:357-62.

80. Post $J$, Ilich Ernst JZ. Controversies in vitamin D recommendations and its possible roles in nonskeletal health issues. J Nutr Food Sci. 2013;03:1-5.

81. Ross AC, Taylor CL. Yaktine AL. Calcium Vitamin D: Valle HB Del; 2011.

82. Endocrine S. Evalutation, treatment, and prevention of vitamin D deficiency: An endocrine society clinical practice guideline. 2011.

83. Vieth $\mathrm{R}$. Why the optimal requirement for Vitamin D3 is probably much higher than what is officially recommended for adults. J Steroid Biochem Mol Biol. 2004;89-90:575-9.
84. Cannell J, Hollis B. Use of vitamin D in clinical practice. Altern Med Rev. 2008;13:6-20.

85. Heaney RP. Assessing vitamin D status. Curr Opin Clin Nutr Metab Care. 2011;14:440-44.

86. Vieth R. Vitamin D supplementation, 25-hydroxyvitamin D concentrations, and safety. Am J Clin Nutr. 1999;69:842-56.

87. Bischoff-Ferrari HA, Giovannucci E, Willett WC, Dietrich T, Dawson-Hughes B. Estimation of optimal serum concentrations of 25-hydroxyvitamin D for multiple health outcomes. Am J Clin Nutr. 2006;84:18-28.

88. Pramyothin P, Holick MF. Vitamin D supplementation: guidelines and evidence for subclinical deficiency. Curr Opin Gastroenterol. 2012;28:139-50.

89. Holick MF, Binkley NC, Bischoff-Ferrari HA, Gordon CM, Hanley DA, Heaney RP, et al. Evaluation, treatment, and prevention of vitamin D deficiency: an Endocrine Society clinical practice guideline. J Clin Endocrinol Metab. 2011;96:1911-30.

90. Hollis BW. Circulating 25-hydroxyvitamin D levels indicative of vitamin D sufficiency: implications for establishing a new effective dietary intake recommendation for vitamin D. J Nutr. 2005;135:317-22.

91. Engelman CD. Vitamin D recommendations: the saga continues. J Clin Endocrinol Metab. 2011;96:3065-6.

92. Barger-Lux MJ, Heaney RP, Dowell S, Chen TC, Holick MF. International original article vitamin D and its major metabolites: Serum levels after graded oral dosing in healthy men. Osteoporos Int. 1998;25:222-30.

93. Lappe J, Cullen D, Haynatzki G, Recker R, Ahlf R, Thompson K. Calcium and vitamin $d$ supplementation decreases incidence of stress fractures in female navy recruits. J Bone Miner Res. 2008;23:741-9.

94. Dawson-Hughes B, Heaney RP, Holick MF, Lips P, Meunier PJ, Vieth R. Estimates of optimal vitamin D status. Osteoporos Int. 2005;16:713-6.

95. Heaney RP, Davies KM, Chen TC, Holick MF, Janet Barger-Lux M. Human serum 25-hydroxycholecalciferol response to extended oral dosing with cholecalciferol. Am J Clin Nutr. 2003;77:204-10.

96. Webb AR, Kline L, Holick MF. Influence of season and latitude on the cutaneous synthesis of vitamin D3: exposure to winter sunlight in Boston and Edmonton will not promote vitamin D3 synthesis in human skin. J Clin Endocrinol Metab. 1988;67:373-8.

97. Valtueña J, Dominguez D, Til L, González-Gross M, Drobnic F. High prevalence of vitamin D insufficiency among elite Spanish athletes the importance of outdoor training adaptation. Nutr Hosp. 2014;30:124-31.

98. Villacis D, Yi A, Jahn R, Kephart CJ, Charlton T, Gamradt SC, et al. Prevalence of Abnormal Vitamin D Levels Among Division I NCAA Athletes. Sports Health. 2014;6:340-7.

99. Constantini NW, Arieli R, Chodick G, Dubnov-Raz G. High prevalence of vitamin D insufficiency in athletes and dancers. Clin J Sport Med. 2010;20:368-71.

100. Holick MF. The vitamin D epidemic and its health consequences. J Nutr. 2005;135:27395-48.

101. Van den Ouweland J, Fleuren $H$, Drabbe $M$, Vollaard $H$. Pharmacokinetics and safety issues of an accidental overdose of 2,000,000 IU of vitamin D3 in two nursing home patients: a case report. BMC Pharmacol Toxicol. 2014;15:57.

102. Suda T, Ueno Y, Fujii K, Shinki T. Vitamin D and bone. J Cell Biochem. 2003;88:259-66S.

103. Zittermann A. Vitamin D and cardiovascular disease. Anticancer Res. 2014;34:4641-648.

104. Kidd PM. Vitamins D and K as pleiotropic nutrients: clinical importance to the skeletal and cardiovascular systems and preliminary evidence for synergy. Altern Med Rev. 2010;15:199-222.

105. Gundberg CM, Lian JB, Booth SL. Vitamin K-dependent carboxylation of osteocalcin: friend or foe? Adv Nutr An. 2012;3:149-57.

106. Mizuguchi M, Fujisawa R, Nara M, Nitta K, Kawano K. Fourier-Transform infrared spectroscopic study of Ca2 + -binding to osteocalcin. Calcif Tissue Int. 2001;69:337-42.

107. Fitzpatrick TB, Basset GJC, Borel P, Carrari F, DellaPenna D, Fraser PD, et al. Vitamin deficiencies in humans: can plant science help? Plant Cell. 2012;24:395-414.

108. Binkley NC, Krueger DC, Kawahara TN, Engelke JA, Chappell RJ, Suttie JW. A high phylloquinone intake is required to achieve maximal osteocalcin $Y$-carboxylation. Am J Clin Nutr. 2002;76:1055-60.

109. Akiyama Y, Hara K, Tajima T, Murota S, Morita I. Effect of vitamin K2 (menatetrenone) on osteoclast-like cell formation in mouse bone marrow cultures. Eur J Pharmacol. 1994;263:181-5. 
110. Akiyama Y, Hara K, Kobayashi M, Tomiuga T, Nakamura T. Inhibitory Effect of Vitamin K2 (Menatetrenone) on Bone Resorption in Ovariectomized Rats. A Histomorphometric and Dual Energy X-Ray Absorptiometic Study. The Japanese Journal of Pharmacology. 1999;80(1):67-74.

111. Feskanich D, Weber P, Willett WC, Rockett H, Booth SL, Colditz GA. Vitamin $\mathrm{K}$ intake and hip fractures in women: a prospective study. Am J Clin Nutr. 1999;69:74-9.

112. Masterjohn C. Vitamin D toxicity redefined: vitamin $\mathrm{K}$ and the molecular mechanism. Med Hypotheses. 2007;68:1026-34.

113. El Asmar MS, Naoum JJ, Arbid EJ. Vitamin k dependent proteins and the role of vitamin $\mathrm{k} 2$ in the modulation of vascular calcification: a review. Oman Med J. 2014;29:172-7.

114. Hamidi MS, Cheung AM. Vitamin K and musculoskeletal health in postmenopausal women. Mol Nutr Food Res. 2014;58:1647-57.

115. Iwamoto J. Vitamin K2 therapy for postmenopausal osteoporosis. Nutrients. 2014;6:1971-80.

116. Murakami K, Yamanaka N, Ohnishi K, Fukayama M, Yoshino M. Inhibition of angiotensin I converting enzyme by subtilisin NAT (nattokinase) in natto, a Japanese traditional fermented food. Food Funct. 2012;3:674-8.

117. Dowd P, Hershline R, Ham SW, Naganathan S. Mechanism of action of vitamin K. Nat Prod Rep. 1994;11:251-64.

118. Fusaro M, Crepaldi G, Maggi S, Galli F, D’Angelo A, Calò L, et al. Vitamin K, bone fractures, and vascular calcifications in chronic kidney disease: an important but poorly studied relationship. J Endocrinol Invest. 2011;34:317-23.

119. Konakion ${ }^{\circledast}$. Konakion ${ }^{\oplus}$. 2010. p. 1-6.

120. Craciun AM, Wolf J, Knapen MH, Brouns F, Vermeer C. Improved bone metabolism in female elite athletes after vitamin $\mathrm{K}$ supplementation. Int J Sports Med. 1998;19:479-84.

121. Visser M, Deeg DJ, Puts MT, Seidell JC, Lips P. Low serum concentrations of 25-hydroxyvitamin $\mathrm{D}$ in older persons and the risk of nursing home admission. Am J Clin Nutr. 2006;84:671-672.

\section{Submit your next manuscript to BioMed Central and take full advantage of:}

- Convenient online submission

- Thorough peer review

- No space constraints or color figure charges

- Immediate publication on acceptance

- Inclusion in PubMed, CAS, Scopus and Google Scholar

- Research which is freely available for redistribution 